\title{
School Power through Cooperation and Shared Vision
}

\author{
Anila Plaku-Bratja (PhD Candidate) \\ University "Aleksander Moisiu", Durres, Albania \\ e.mail: anilabratja@gmail.com
}

Doi:10.5901/ajis.2013.v2n2p281

\begin{abstract}
In the 21st century "knowledge" has knocked with a new paradigm, giving it the strength that has always characterized it, but at the same time, the fragility along the new and uncertain environment. Policies and reforms for a knowledge society are closely linked to educational institutions in their continuous improvement. Thus, strengthening of school through effective management is required to promote long-term success. This study, aiming at the creation of a collaborative environment in school, influences on its effective management. Its aim is to give the answer to the question why older models of leadership and culture of isolation have led to mismanagement of educational institutions. Such factors as leadership philosophy, old models, hierarchical view of authority and power, and low level of trust are in the focus of the study. Through qualitative research, this study provides findings based on interviews with school leaders, specialists in Educational Directorate of Durrës and a focus group, in a broad study extent. This study aims at improving school management to promote success and achievement.
\end{abstract}

Keywords: Cooperation, school leadership, shared vision, effective management, action plan.

\section{Introduction}

After the 90 `s Albania was in need for rapid change, which came as indispensable needs in education, affecting its structure and contents. They aimed at providing education with flexibility and adaptations to changes as society itself underwent during this transition period. At first glance the terms change, reform, transformation processes gave the idea of moving forward but advertising success through the cold language of letters, featuring new quality if deported to changing aspects, the quality and process itself and schools as institutions "breathe" through a reality called "school".

\section{Strengthening and promoting school success}

Fullan (2003) asserts that it is not enough just to study factors associated with success and failure of innovation and educational policies. It is not acceptable to mention the planned change from that which occurs spontaneously or naturally. If wanting to change something, we have to become aware of an understanding that deeper educational change should be in its entirety. We will learn that it is not possible to avoid "the problem of change." But, meanwhile, we will learn that we can live with it more productively. Evers (2008) analyzes such reforms fail because they are imposed rather than systemic. They imposed on a system that operates through such a management structure, which by their nature cannot build an effective learning community and support.

Sergiovanni (2009) states that external authority functions in teachers and students response. But external authority tends to make them dependent upon response. Good subordinates always do what is required, but only just. Overcoming daily competence, commitment and performance of daily requests from people to become subordinate to the successor requires a different kind of theory and practice. Subordinates respond to external authority and respond to followers' ideas, values, beliefs and goals. According to Drucker (1999), a lot is heard about "the end of the hierarchy." It's a noisy nonsense. In every institution the person who has the final authority is the President, someone who takes the final decision and expects others to implement them. In a shared-risk situation or any situation that suddenly comes sooner or later, everyone's survival depends on a clear command. If the ship risks sinking the captain does not squat but gives orders. Other situations require brainstorming same institution. Others require group work, and so on.

Senge (2004) argues that the creation of a shared vision is part of a broader activity, leading to the development of venture ideas, her vision, purpose or mission, and core values. The main idea answer three critical questions: "What?", "Why?" and "how". Vision is "What?" the picture of the future we want to create. Purpose (or "mission") is "Why?" The 
answer to the question of organization "Why do we exist?" The core values answer the question "How do we want to act in accordance with the mission, along paths towards achieving the vision?" Values of an organization include integrity, honesty, sincerity, freedom, equal opportunity, merit or loyalty. Norms and values associated with ambitious concepts of learning and growing improvement in practice and not vice versa. Improving the school is not obtained by all staff in the audience, proving and swearing that all students can learn, not that it means that all staff will again return to the same job to do once it has always done. Only changes in practice can bring real change in values and norms. (Pierce and Stapleton, 2011)

Successful leaders talk about a special mission of the school, emphasizing innovation and improvement. It is imperative that the director share his/her ideas with teachers, so that they understand school goals and work together to achieve them (Sadker and Sadker, 1995). Elmore (2011) mentions that Susan Rosenholtz 1986, based on an empirical study on variations in the effectiveness of schools, noted that there were two types of very different school cultures or living things. She discovered that the teacher collegiality leaders really do not have a direct impact on students' performance, but indirectly affects, when deciding on goals at school, in the recruitment of new teachers, the socialization and evaluation. A system can be open or closed. The philosophy of the school closure seems isolated from its environment, with emphasis on physical planning, control, stability and predictability. Meanwhile an open system considers the organization as a living biological entity and exchange inputs and outputs where the organization interacts with the environment. In such a sense of organization can be seen as interdependent internally and externally. Understanding the organization as a system and understanding the internal and external factors brings changes (Senge, 2004).

In this study there are addressed areas such as environmental assessment of the school, having a clear vision and setting in motion the staff, the sensitivity and the relationship of trust between the parties. View from this point it is interesting addressing a somewhat more practical context of the process. This is because the ideas, no matter how good I very good either, they can come by itself, because reform does not mean, simply put in the recent policy implementation. Reform means to change the culture of classrooms, schools, districts, universities, and so on (Fullan, 2010).

\section{Methodology}

This study aims to show that the creation of a collaborative environment in school affects its effective management. It aims to answer the question why the old models of leadership and culture of isolation brought mismanagement of educational institutions? Factors such as: philosophy of leadership, older managerial models, hierarchical view of authority and the low level of trust between the parties are the focus of study. This study is based on qualitative research, using school records, interviews with executives and specialists of Regional Education Department (RED) in Durres, and the perception of teachers from two focus groups.

3.1 Study of documents, have been studied following regulations and guidelines, observing their certification in schools in the study, such as: Instruction no. 41, dated 17:10. 2007 For the format of the annual school plan, Instruction no. 1, dated 14:01. 2009 For qualification 2008-2009.

3.2 Interviews: In this study interviews were conducted with 30 head teachers of secondary 9-year schools without selection criterion, but with a stretch in all Durres. Unstructured interviews were developed, including general and specific questions about vision and promoting innovation, cooperation with teachers of the school leaders, trust between the parties and staff development. Have interviewed three experts from RED Durres, according to distribution departments, focusing on annual and medium-term plan, school autonomy, the degree of responsibility and accountability on the part of leaders and school appropriate capacities.

3.3 Focus groups, and data were obtained from two focus groups with 10 teachers, a focus group with teachers in Durres Municipality and the other referring to suburban areas. At issue was the theme of the degree of cooperation with the teaching staff leadership, support, and application requirements for innovation in educational contexts.

\section{Results of the study}

Referring to instruction No.41 dated 17.10.2007 on the format of the annual plan and the continuous demand of RED for a clear structuring of this format, school leaders continue to connect most of their work with the design of a physical plan, rather than the planning process. In the context of teachers, they say that planning is a tedious process, which do not 
benefit from, rather waste time, as directors will decide as they want. School leaders are more dependent and tend to apply what they say than to take the opinion of the staff. But, as some say, they have the personality and leadership and able to find the right path. RED specialists claim that it actually worked, or no vision or leader centralizes power. They only followed formal procedures. Plans have problems in their design, because do not bring to school specifications (basic condition), following the general.

If we refer to the leaders building relationships with the staff, $53 \%$ of respondents said they prefer to maintain distance relationships as official meetings or meetings through planning controls by internal audit, $30 \%$ try to merge with the head teacher-table discussions and preferred round or events seemingly spontaneous to feel equal and speak freely, while $17 \%$ mainly as situations dictates. While teachers themselves say that education work is tedious. Many things are required by imposition. The teacher should ask more, because it is he/she who will implement policies. Curricula often undergo changes and apply to the desired text. RED specialists say visionary leader must search through questionnaires, surveys conducted with all stakeholders. Be clear and to know why this exploration, knowing how to build questionnaires and interviews, in order to receive data to identify service issues.

It is interesting the perception of managers regarding the level of risk taking in the promotion of initiatives / projects in school, $83 \%$ of managers say they do not like to take initiatives or projects that are riskier, claiming in a way the fact that they cannot accept failure in their work. So they feel safe when initiatives / projects are clear and successful. While only $17 \%$ argue that risk taking, which is not in contradiction with the laws, makes school open and require more management. Even the failure of an initiative is successful, says a new leading head-teacher, as for her learning is more about how can be managed in the future. But experts say that RED appointed leaders are not part of the competition, so they have not shown their intellectual capacity and management in running the school. Lack of competition does not highlight values to evaluate each management capabilities and their vision for the school.

In terms of evaluation and interaction with staff, managers of rural schools try to convey their concern that comes from the city under which little or adaptation activities are dedicated to the culture of the area. Only $30 \%$ of managers see the advantage, as it promotes interaction and tracking of innovations, $60 \%$ sees it as a disadvantage for a successful direction and $10 \%$ did not comment. $60 \%$ of managers reflect negatively on the reports made between new teachers (appointed last 3-5 years) and older generation. They say for failing to support young people by older teachers, who are often skeptical about the work and the preparation of young people, and young teachers say that teachers are old and traditional. And $27 \%$ say they have encountered difficulties in the integration process, but over time the cooperation and exchange of experience is reached. Only $13 \%$ of executives say that in their school there is a tendency for young people to find support from existing school staff and adapting quickly to its culture. Even head-teacher $\mathrm{X}$ indicates inclusion of a school teacher in new projects, while the more motivated at work, which has fostered creativity in school follow a new spirit. While another interview ends by saying: "I want to break the prejudice that it is a village school. This is an institution that should promote civic and intellectual values".

Teachers say they are not encouraged and promoted by the need to bring innovation. Some teachers are old and have no desire to develop further as lacking motivation and incentives. While new teachers prejudice for lack of skill by calling teaching an undesired profession. Teachers in rural areas claim that is easily to implement the tasks set by the head of school, because he/she knows better what the right choice for the school is. Generally, considering particular cases, teachers expressed reservations towards the old head-teachers by calling them traditional. They brought cases on the successful experience of some young directors, but according to them, are not easy to change the direction of the previous routine. RED specialists say good leaders should delegate tasks to staff and management team of teachers. Lack of delegation of powers creates distance and centralized staff. This comes as mistrust or to staff or overestimation of leader's authority.

\section{Discussion of results}

Projecting work in an academic institution is quite different in plan process. If we refer to the former, the process is not only long, but mostly related to the work conception / idea; like an architect. A successful leader is not only a good architect, but above all, a master architect who directs the school not only in the present, but on all future projects, successfully dealing with dynamic processes in the school.

Education policies play a central role in the development of education, and the development of the country life. The programs are the best estimate of what will happen in the future but should be modified on the basis / foundations continued to consider what will happen during implementation (European Commission, 2004). For countries which for 
years have been indoctrinated is not an easy path, since the system through various forms of self-isolation established a mental model to individual. Gardner (2003), focusing on issues of education in the future, as a conservative institution analyzes clearly in saying, 'Do not forget what meant having been a teacher in Eastern Europe during the last fifty years. It was considered true, beautiful and good in 1950, might not be such today, however, individuals prepared in prior periods, parents and teachers, but not the least, cannot throw their beliefs which were embedded in the mind for a long time. According to the definition of the English poet and educator Mathew Arnold, they "migrate between two worlds, one dead and the other powerless to be born."

It is necessary for the head-teachers to be appointed by competition, as well as teacher candidate implementing as such the new undergraduate education strategy and law. In this way the capacity of institutions select appropriately school teachers and leaders, as according to Fullan (2003) provide professional autonomy of teachers' groups, who do not have the commitment and ability to convey their work with disciplined knowledge and moral purpose, will not do more than to spend resources.

However in Durres there are positive examples of successful leaders, who include some leadership styles, the head-teachers, motivators, associates, converters, catalysts or crisis manager, using various forms of cooperation, which brings empowerment to the school. Educational institutions in order to return to environments where teachers collaborate and share ideas, new teachers are welcomed by teachers with experience and engage in activities or projects by management, and increase forces by multiplying their previous capacity. On the other hand teachers with seniority are easier to apply technology updates with youth. Such schools have created a culture of their own, as this is no longer is the prerogative of school center, but also in rural areas positive examples are observed. Even to strengthen this cooperation, they welcome previous leaders with experience, supporting young leaders, where men help and support women leaders. Required that such positive examples found is stretched in other schools, where real lack of cooperation happens because cooperation is not only the creation of working groups, but above all the common will, discussing views through debate and systemic thinking.

Lack of inspection at the RED sector has damaged specialists in direct contact with the ground. NIE was established by Council of Ministers decision N.56, dated 03.02.2010, "On the establishment of National Inspectorate of Education ". Meanwhile NIE specialists do not have the opportunity to observe schools all the time. This is because inspections are to be understood as a contribution, not as segmented and sporadic checks. Managers need support, exchange of ideas, experiences and ongoing training. On the other hand, through frequent inspection, specialists realize that there are real needs for schools, and it is necessary to provide the service as close to the service provider, based in chains of shorter boundaries. Decentralization does not justify the lack of training of the inspection department at the education departments, as is necessary for both the continuity of mutual relations, relations that are closely related to terrain and carries the right to direct inspection specialists, this responsibility is part of NIE since 2010. As Fullan said (2003) centralization leads to excessive control and decentralization leads to chaos. We already know for a long time that the change from the top down does not work (things cannot be done by force).

\section{Conclusions and recommendations}

In order to empower education institutions, they need strengthening cooperation at all management levels, in order to make tasks easier by creating a supportive work environment. Gradually this report brings mutual trust, desire and willingness of individuals to share thoughts with each other, the older teachers with new teachers, the management team of head-teachers and teaching staff, school cooperation with other levels of hierarchy. Just when individuals become part of the organization, they integrate, gradually gaining behavior, beliefs, norms and values. That organizational culture should function properly within the broader culture of the society, it must have enough elements in common with its underlying values. If closed structures are created, controlling more than cooperative, hardly do they promote successful long-term changes. Capacity building relates to the powers, resources and motivation. According to Fullan (2008) individuals and groups increase their capacity, whether possess and continue to develop knowledge and skills, if the aim and use of resources (time, ideas, expertise, money) are wisely done and if you commit to using energy to accomplish things equally significant collectively and continuously. Therefore is necessary:

- To appoint school leaders with competition and on the basis of the merit system and educational service will be more qualitative and productive.

- School autonomy should go hand in hand with capacity building, to be faced and successfully overcome innovations. 
- To establish cooperation rather than procedure, but as an escalation process.

- Successful leadership is achieved by leaders who assume all roles depending on the situation and problems. Strengthening school means empowering the individual, as such proper individuals continuously investing in their capacity.

\section{References}

Drucker, F.P. (1999). Management Challenges for the 21st Century. Harper Collins Publishers, 20.

European Commision (2004). Project Cycle Management Aid Delivery Methods. 1, 41.

Elmore, R. (2011). Reforma shkollore nga brenda jashtë. U.F.O Press, 66-67.

Evers, James. Crisis in school management, E-Manuscript, 2008, 10

Fullan, M. (2003). Forcat e ndryshimit në arsim. ISP, Tiranë, 5, 42.

Fullan M. (2003). The moral imperative of school leadership. Corwin Press, Inc, 7

Fullan, M. (2010). Kuptimi i ri i ndryshimit në arsim. CDE, Tiranë, 22.

Fullan, M. (2008). The six secrets of change. Jossey-Bass, 57

Gardner, H. (2003). Mendja e disiplinuar. Erik, 33-40.

Llambiri, Stavri. (2008). Mbi planin vjetor të shkollës. Drejtimi i shkollës: Udhëzues për drejtuesit e shkollës, IKT, Tiranë, 54-67.

Pierce, P. dhe Stapleton, L.D. (2011). Drejtori i shkollës i shekullit XXI. Kufijtë e ndryshimit. U.F.O. Press, 16.

Sadker, P.M. dhe Sadker, M.D. (1995). Mësuesit, shkollat dhe shoqëria. Eureka, 178.

Senge, P. (2004). The Fifth discipline: The art \& practice of the learning organization. New York, 209, 274.

Sergiovani, T. (2009). The pricipalship: A reflective practice perspektive. Allyn \& Bacon, 89. 
